\title{
Effect of Single Oxide Fluxes on Morphology and Mechanical Properties of ATIG on 316 L Austenitic Stainless Steel Welds
}

\author{
Abdeljlil Hdhibi \\ Mechanical Engineering Department \\ College of Engineering \\ Prince Sattam Bin Abdulaziz University \\ Al Kharj, Saudi Arabia and \\ Preparatory Engineering Institute of \\ Nabeul (IPEIN), Tunisia \\ a.hedhibi@psau.edu.sa \\ Abousoufiane Ouis \\ Mechanical Engineering Department \\ College of Engineering \\ Prince Sattam Bin Abdulaziz University \\ Al Kharj, Saudi Arabia \\ a.ouis@psau.edu.sa
}

\author{
Kamel Touileb
Mechanical Engineering Department \\ Kamel Touileb
Mechanical Engineering Department \\ College of Engineering \\ Prince Sattam Bin Abdulaziz University \\ Al Kharj, Saudi Arabia \\ k.touileb@psau.edu.sa
}

(tonilebopsau.edusa

\author{
Rachid Djoudjou \\ Mechanical Engineering Department \\ College of Engineering \\ Prince Sattam Bin Abdulaziz University \\ Al Kharj, Saudi Arabia \\ r.djoudjou@psau.edu.sa
}

\begin{abstract}
Tungsten inert gas (TIG) is a wide common process used in fabrication due to its low cost equipment, high quality and accuracy welds but has low productivity related to the low penetration depth in single pass. A new perspective, the Activated Tungsten Inert Gas (ATIG), in which the same equipment as TIG is used, except that a thin layer of activated flux is deposited on a workpiece surface. In this work, eight kinds of oxides were tested on 316L austenitic stainless steel. Three levels of welding current were used to study the effect of different activating fluxes on weld bead geometry and mechanical properties. X-ray Photoelectron Spectroscopy (XPS) was used for the first and the second level energy for different ATIG welds to analyze the relationship between the weld shape and oxygen content in welds. The experimental results showed that the weld profile is related to the thermodynamic stability of selected oxides and in relation to the energy provided. ATIG with $\mathrm{TiO}_{2}, \mathrm{SiO}_{2}, \mathrm{MnO}_{2}$ oxides presented the deepest welds followed by $\mathrm{Cr}_{2} \mathrm{O}_{3}, \mathrm{Fe}_{2} \mathrm{O}_{3}$, and $\mathrm{ZnO}$. Finally $\mathrm{ZrO}_{2}$, CaO oxides had no effect on the weld depth. The ATIG welded joint showed better tensile strength than TIG. The ATIG hardness measurements carried out showed also better if not the same as TIG weld except for the Silicon oxide weld. Results of the impact test showed that, except for the titanium dioxide $\mathrm{TiO}_{2}$ which has a good benefit, the weldment using the other oxide fluxes exhibits worse withstanding to sudden shock than TIG welding.
\end{abstract}

Keywords-ATIG; austenitic stainless steel; weld shape; mechanical properties

\section{INTRODUCTION}

TIG welding uses a non-consumable tungsten electrode and an inert gas. In this process, an electric arc is formed between the tungsten electrode and the base metal. However, there are a few limitations of the TIG welding process, like low penetration depth, and if the workpiece thickness is greater than $3 \mathrm{~mm}$ joint edge preparation and multiple passes are required to fill the joint completely. TIG welds are also affected by cast-tocast compositional variation in the base metal being welded [1, 2]. These limitations can be overcome by using ATIG welding. This technic was invented in the 1960's by researchers at the Paton Electric Welding Institute (PWI) in Ukraine [3, 4]. Few data are available in the open literature about the activating flux composition. Such data are very important to determine the weld penetration improvement. The mechanism related to deep penetration is linked to:

\section{A. Arc Constriction [5-7]}

This phenomenon can occur by two means:

- The interaction between the peripheral negative charge (electrons outside the arc) and the neutral particles (atoms and molecules) formed from the dissolution of flux components causes the constriction of the arc, leading to the increase of the welds depth.

- The flux acts as insulating layer reducing the current density of the outer arc radius and increases the current density in the center as well as magnetic force (Lorentz 
force) in the weld pool which lead to the increasing of weld depth.

\section{B. Marangoni Convection [8-10]}

During TIG welding, without surfactants elements like sulfur, oxygen, selenium, and tellurium, the surface tension gradient is negative and the convection movement is centrifugal leading to a shallow penetration. The addition of activated flux induces an inversion of the convection current and changes the sign of the surface tension resulting in a centripetal convection movement, to the increase of penetration depth. High sulfur percentage weld beads are sensitive to centerline cracking and heat affected zone (HAZ) cracking. On the other hand, very low sulfur content can lead to irregular weld penetration. For acceptable penetration without a risk of crack, the sulfur range should vary from $0.005 \%$ to $0.030 \%$ for 316 stainless steel with the suggested $\mathrm{Cr}_{\mathrm{eq}} / \mathrm{Ni}_{\mathrm{eq}}$ ratio range from 1.43 to 1.9 [11]. This element can be provided as pasted flux on the workpiece to improve the depth of welds [12]. On the other hand, the addition of 500ppm of $\mathrm{SO}_{2}$ in shield gas improves the $\mathrm{D} / \mathrm{W}$ ratio by $80 \%$ [13]. As for selenium, an addition of $0.1 \%$ by weight of Se in steel reduces its superficial tension by $30 \%$ [14]. While the variations of $\mathrm{O}_{2}$ range from 600ppm to $1200 \mathrm{ppm}$, can lead to an increase of penetration from $15 \%$ to $45 \%$ for the 1010 steel [15]. The activation of the cited elements is limited by a reversal temperature beyond which they don't affect the weld morphology [14]. Authors in [16] showed that oxygen as active element is active in pure liquid iron in the range of $150-300 \mathrm{ppm}$. Above this range the temperature coefficient of surface tension becomes zero or negative leading to shallow and wide weld bead. According to a study [17], the oxygen content in the weld metal in the range of $70 \mathrm{ppm}-300 \mathrm{ppm}$, can increase the geometric parameter $\mathrm{D} / \mathrm{W}$ from 1.5 to 2 times.

Many works have been conducted using single flux (oxide or halide type) to study their individual effect on the morphology and the mechanical properties [12, 18-25]. Due to the complexity of the reactions in the weld pool and interconnection with the welding arc, a single component flux cannot meet a good morphology and mechanical properties requirements. On the other hand, several studies were conducted in order to find the suitable flux compositions. Binary fluxes have been developed in order to get optimum percentages of binary flux components that can improve the aspect and the shape as well as the mechanical properties of welds [1, 27-29]. In addition, other studies were devoted to ternary flux where statistical programs were used to develop a formulation on the percentages of the ternary flux components to enhance depth and mechanical properties of welds [30] as well as the effect of the welding parameters and the flux on weld bead geometry, angular distortion and mechanical properties.

In this study, eight different kinds of oxide fluxes $\left(\mathrm{Cr}_{2} \mathrm{O}_{3}\right.$, $\mathrm{Fe}_{2} \mathrm{O}_{3}, \mathrm{CaO}, \mathrm{ZnO}, \mathrm{ZrO}_{2}, \mathrm{SiO}_{2}, \mathrm{MnO}_{2}$ and $\mathrm{TiO}_{2}$ ) were used to investigate the effect of single component flux on the morphology, and mechanical properties of 316L stainless steel TIG welds. This study contributes to the understanding of the phenomena that occur in the weld pool.

\section{EXPERIMENTAL PROCEDURE}

This work was conducted on $316 \mathrm{~L}$ stainless steel. The tensile strength of the material is $618 \mathrm{MPa}$, Vickers hardness is $180 \mathrm{HV}$ and melting point is about $1440^{\circ} \mathrm{C}$. Table I lists the chemical compositions of this steel. Plates $6 \mathrm{~mm}$ in thickness were cut into $204 \mathrm{mmx} 204 \mathrm{~mm}$ to have test samples for mechanical testing and weld morphology (Figure 1). Acetone was used to clean and remove dust and contamination.

TABLE I. CHEMICAL COMPOSITION OF 316L STAINLESS STEEL

\begin{tabular}{|c|c|}
\hline SS 316 L & percentage \\
\hline $\mathrm{C} \%$ & 0.018 \\
\hline $\mathrm{Mn} \%$ & 1.30 \\
\hline $\mathrm{Si} \%$ & 0.43 \\
\hline $\mathrm{P} \%$ & 0.034 \\
\hline $\mathrm{S} \%$ & 0.0029 \\
\hline $\mathrm{Cr} \%$ & 16.78 \\
\hline $\mathrm{Ni} \%$ & 10.00 \\
\hline $\mathrm{Mo} \%$ & 2.005 \\
\hline $\mathrm{N} \mathrm{ppm}$ & 321 \\
\hline $\mathrm{Ti} \%$ & 0.0042 \\
\hline $\mathrm{Cu} \%$ & 0.2082 \\
\hline $\mathrm{Co} \%$ & 0.226 \\
\hline
\end{tabular}

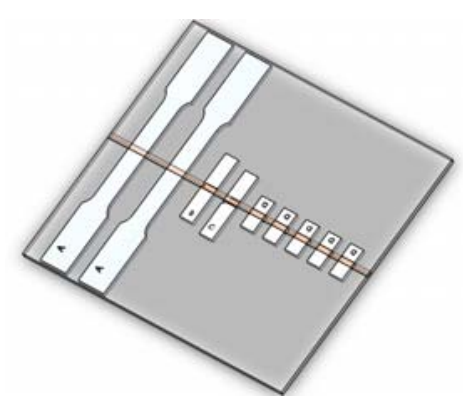

Fig. 1. Different test specimens on welded plate

Eight different kinds of oxide fluxes were used. Table II lists the melting and boiling temperature of the different oxides. Thermodynamic stability of selected oxides is showed in Table III where the stability decreases from left to right. Products have been heated separately in furnace at $150^{\circ} \mathrm{C}$ for 1 hour to eliminate humidity. The powder has been mixed with acetone (1:1 ratio) forming a paste. A brush was used to apply the mixture on the plain surface to be welded. The acetone was allowed to evaporate, so only the flux powder was left on the metal surface. The coating density of flux was about 7$8 \mathrm{mg} / \mathrm{cm}^{2}$, and the flux layer thickness about $0.2 \mathrm{~mm}$. A TIG welding machine was used. A water-cooled torch with a standard $2 \%$ thoriated tungsten electrode rod having diameter of $3.2 \mathrm{~mm}$ has been used for the experiments. The torch was mounted on a motorized carriage as shown in Figure 2. Three series of tests have been carried out with three levels of welding currents (150amp, 540kJ/m-180amp, $680 \mathrm{~kJ} / \mathrm{m}$, $200 \mathrm{amp}, 800 \mathrm{~kJ} / \mathrm{m}$ ). The welding parameters selected for TIG welding are listed in Table IV.

After welding, the samples were cut as shown in Figure 1, far from the welding starting point to be sure that the arc welding was stabilized. Etching operation is necessary to reveal the morphology of the welds and for hardness measurements. Solution of one volume of water and 2 volumes of 
Hydrochloric acid (HCL) and one volume of nitric acid $\left(\mathrm{HNO}_{3}\right)$ was used for etching. The tensile tests were conducted at room temperature. The tests were carried out with a computer control electro-hydraulic servo universal testing machine model WAW-300E and the impact tests with the impact testing machine model JBS-500. Vickers hardness measurement was performed with a digital hardness tester model HVS-50. The tensile, impact, and hardness test were conducted only with 180amp welds (second energy level).

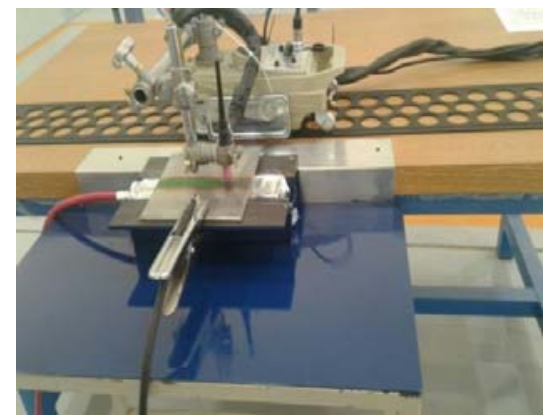

Fig. 2. Experimental setup of TIG welding with flux paste (A motorized carriage, torch-workpiece).

TABLE II. MELTING AND BOILING TEMPERATURE OF USED OXIDES

\begin{tabular}{|c|c|c|}
\hline Oxides & $\mathrm{Tm}(\mathrm{c})$ & $\mathrm{Tb}\left({ }^{\circ} \mathrm{C}\right)$ \\
\hline $\mathbf{C r}_{2} \mathbf{O}_{3}$ & 2435 & 3000 \\
\hline $\mathbf{F e}_{\mathbf{2}} \mathbf{O}_{\mathbf{3}}$ & 1540 & 1987 \\
\hline $\mathbf{C a O}$ & 2613 & 2850 \\
\hline $\mathbf{Z n O}$ & 1975 & $1975^{*}$ \\
\hline $\mathbf{Z r O} \mathbf{O}_{2}$ & 2715 & 4300 \\
\hline $\mathbf{S i O}_{2}$ & 1713 & 2950 \\
\hline $\mathbf{M n O}_{2}$ & 535 & $540 *$ \\
\hline $\mathbf{T i O}_{2}$ & 1843 & 2972 \\
\hline
\end{tabular}

TABLE III. THERMODYNAMIC STABILITY OF SELECTED OXIDES IN DECREASING ORDER

\begin{tabular}{|l|l|l|l|l|l|l|l|}
$\mathrm{CaO}$ & $\mathrm{ZrO}_{2}$ & $\mathrm{TiO}_{2}$ & $\mathrm{SiO}_{2}$ & $\mathrm{Cr}_{2} \mathrm{O}_{3}$ & $\mathrm{ZnO}$ & $\mathrm{Fe}_{2} \mathrm{O}_{3}$ & $\mathrm{MnO}_{2}$ \\
\hline
\end{tabular}

TABLE IV. WELDING PARAMETERS

\begin{tabular}{|c|c|}
\hline Welding speed & $15 \mathrm{~cm} / \mathrm{min}$ \\
\hline Welding current & $(150-180-200) \mathrm{Amp}$ \\
\hline Arc Length & $2 \mathrm{~mm}$ \\
\hline Electrode Tip Angle & $60^{\circ}$ \\
\hline Shield gas on work piece & Argon with flow rate $12 \mathrm{l} / \mathrm{min}$ \\
\hline Shield gas Back side & Argon with flow rate $51 / \mathrm{min}$ \\
\hline Welding mode & Direct current electrode negative \\
\hline
\end{tabular}

\section{RESULTS AND DISCUSSION}

\section{A. Oxygen Content}

XPS was used to analyze the surface chemistry of sectional weld bead, especially the percentages of oxygen remaining in weld bead. The result obtained with the flux $\mathrm{SiO}_{2}$ is reported in Figure 3. Results for two energy levels series for different fluxes are reported in Table $\mathrm{V}$.

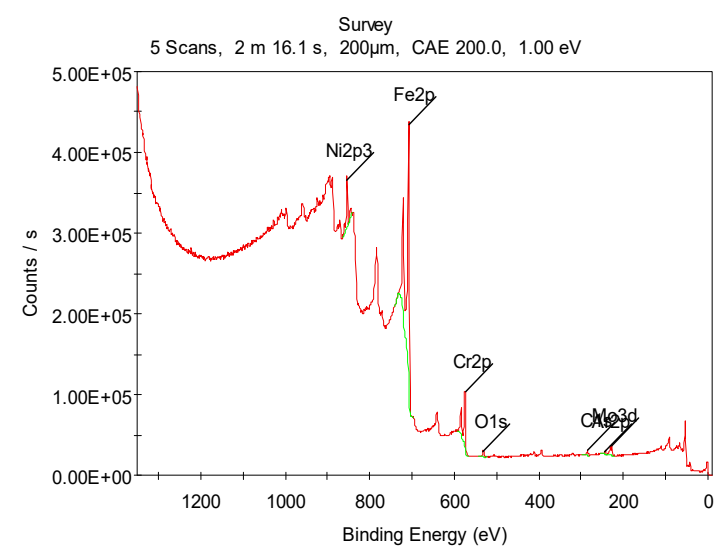

Fig. 3. Oxygen spectrum in ATIG welded bead with $\mathrm{SiO}_{2}$ flux

TABLE V. PERCENTAGES OF O IN ATIG WELD BEAD

\begin{tabular}{|c|c|c|}
\hline Flux & $\mathbf{E}=\mathbf{5 4 0 k J} / \mathbf{m}$ & $\mathbf{E}=\mathbf{6 8 0} \mathbf{k J} / \mathbf{m}$ \\
\hline $\mathbf{S i O}_{2}$ & 4.99 & 6.29 \\
\hline $\mathbf{T i O}_{2}$ & 10.19 & 9.57 \\
\hline $\mathbf{F e}_{\mathbf{2}} \mathbf{O}_{3}$ & 11.07 & 7.33 \\
\hline $\mathbf{M n O}_{\mathbf{2}}$ & 10.9 & 8.84 \\
\hline $\mathbf{C r}_{\mathbf{2}} \mathbf{O}_{3}$ & 23.95 & 11.89 \\
\hline $\mathbf{Z n O}$ & 11.8 & 10.32 \\
\hline $\mathbf{Z r O} \mathbf{O}_{2}$ & 16.85 & 8.53 \\
\hline $\mathbf{C a O}$ & 28.52 & 10.44 \\
\hline
\end{tabular}

\section{B. Effect of the Energy Level $E=540 \mathrm{~kJ} / \mathrm{m}$}

Regarding the fluxes of $\mathrm{CaO}$ and $\mathrm{ZrO}_{2}$, it can be seen that the quantity of oxygen remaining in weld bead is relatively high. This is due to their high thermodynamic stability. With this level of energy there is no or very small quantity liberation of oxygen in weld pool. The melting point of those oxides is very high comparatively to parent metal $\left(\mathrm{T}_{\mathrm{m} 316 \mathrm{~L}}=1440^{\circ} \mathrm{C}\right)$ the gradient of temperature is high, so a high energy is needed to melt them:

$$
\begin{aligned}
& \Delta \mathrm{T}\left(\mathrm{ZrO}_{2}-316 \mathrm{~L}\right)=2715-1440=1275^{\circ} \mathrm{C} \\
& \Delta \mathrm{T}(\mathrm{CaO}-316 \mathrm{~L})=2613-1440=1173^{\circ} \mathrm{C}
\end{aligned}
$$

As for the flux of $\mathrm{Cr}_{2} \mathrm{O}_{3}$ it is characterized by its high melting and boiling temperature, a lot of energy is necessary to melt or vaporize it, that's why a quantity of oxygen remains in the weld bead. $\mathrm{Cr}_{2} \mathrm{O}_{3}$ has moderate thermodynamic stability.

$$
\Delta \mathrm{T}\left(\mathrm{Cr}_{2} \mathrm{O}_{3}-316 \mathrm{~L}\right)=2435-1440=995^{\circ} \mathrm{C}
$$

As for the fluxes of $\mathrm{ZnO}, \mathrm{MnO}_{2}$, and $\mathrm{Fe}_{2} \mathrm{O}_{3}$, they have low stability, but manganese dioxide, with its low melting point of $535^{\circ} \mathrm{C}$, can liberate easily its oxygen.

$\Delta \mathrm{T}(\mathrm{ZnO}-316 \mathrm{~L})=1975-1440=535^{\circ} \mathrm{C}$ (less energy required to melt it)

$$
\Delta \mathrm{T}\left(\mathrm{Fe}_{2} \mathrm{O}_{3}-316 \mathrm{~L}\right)=1540-1440=100^{\circ} \mathrm{C} \text { (easy to melt) }
$$

Finally, the fluxes $\mathrm{SiO}_{2}, \mathrm{TiO}_{2}$ : Their standard Gibb's energies of formation as well as their boiling point are close.

$$
\Delta \mathrm{T}\left(\mathrm{SiO}_{2}-316 \mathrm{~L}\right)=1713-1440=273^{\circ} \mathrm{C}
$$


$\Delta \mathrm{T} \quad\left(\mathrm{TiO}_{2}-316 \mathrm{~L}\right)=1843-1440=403^{\circ} \mathrm{C}$, so less energy is required to melt them.

\section{Effect of the Energy Level $E=680 \mathrm{~kJ} / \mathrm{m}$}

In this case, the low level of oxygen remaining in weld bead means that the oxygen was liberated. This element contributes to having centripetal convection of weld bead leading to full penetrated welds. Maybe there is some oxygen trapped in the weld bead due to the lack of protection effectiveness of the melt.

\section{WELD MORPHOLOGY:}

The weld morphology is characterized by the penetration depth $\mathrm{D}$ and the bead width $\mathrm{W}$.

\section{A. Effect of Different Fluxes on Weld Morphology with a Current of 150amp - E=540kJ/m}

Figure 4 shows the morphology of TIG welds with and without fluxes and Figure 5 shows the width to depth penetration. It can be seen that $\mathrm{TiO}_{2}, \mathrm{SiO}_{2}$ and $\mathrm{MnO}_{2}$ oxides permit to get total penetration weld bead followed by $\mathrm{Cr}_{2} \mathrm{O}_{3}$, $\mathrm{Fe}_{2} \mathrm{O}_{3}$ and $\mathrm{ZnO}$ with good penetration of around $5 \mathrm{~mm}$. Finally moderate penetration welds occur with $\mathrm{ZrO}_{2}$ and $\mathrm{CaO}$ oxides. The depth to width ratio $\mathrm{R}$ is greater than 0.7 for $\mathrm{TiO}_{2}, \mathrm{SiO}_{2}$, $\mathrm{Cr}_{2} \mathrm{O}_{3}$ oxides and close to 0.7 for $\mathrm{MnO}_{2}$. It decreases to 0.55 for $\mathrm{Fe}_{2} \mathrm{O}_{3}$ and $\mathrm{ZnO}$. But it goes down to 0.4 for $\mathrm{ZrO}_{2}$ and $\mathrm{CaO}$. $\mathrm{ZrO}_{2}$ and $\mathrm{CaO}$ oxides behave as pure metals promoting a wide and shallow weld bead. On the other hand, $\mathrm{TiO}_{2}$ and $\mathrm{SiO}_{2}$, and at a less degree $\mathrm{Cr}_{2} \mathrm{O}_{3}$, significantly increase the weld depth to weld bead width ratio.

\section{B. Effect of Different Fluxes on Weld Morphology with a Current of 180amp - E=680kJ $/ \mathrm{m}$}

As revealed with XPS analysis, increasing the welding current increases the temperature in weld pool leading to more liberation of oxygen. Four fluxes out of eight $\left(\mathrm{TiO}_{2}, \mathrm{SiO}_{2}\right.$, $\mathrm{Fe}_{2} \mathrm{O}_{3}$ and $\mathrm{MnO}_{2}$ ) presented total penetration of welds as shown in Figure 6. In this case, the positive tension gradient temperature coefficient controls the melt metal movement in the weld.

\section{Effect of Different Fluxes on Weld Morphology with a} Current of 200amp - E=800kJ/m

The penetration is total for almost all oxides used except zirconium and calcium oxides as shown in Figure 7. In this case, the movement of liquid is from the center to the edges.

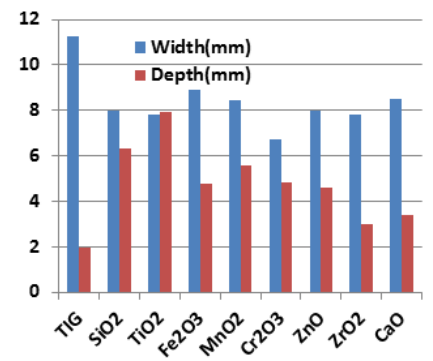

Fig. 4. Morphology of TIG and ATIG welds (I=150A, V=15Cm/min)

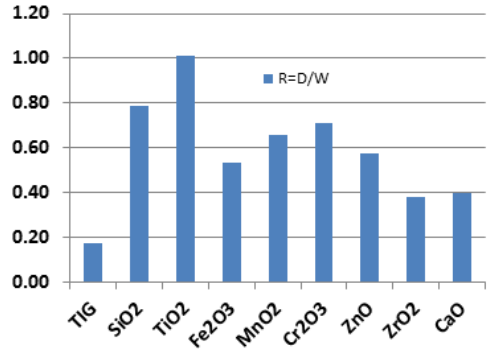

Fig. 5. Width to depth ratio of TIG and ATIG welds (I=150A, $\mathrm{V}=15 \mathrm{Cm} / \mathrm{min}$ )

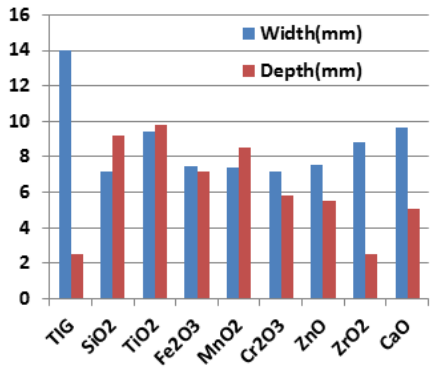

Fig. 6. Morphology of TIG and ATIG welds ( $\mathrm{I}=180 \mathrm{~A}, \mathrm{~V}=15 \mathrm{Cm} / \mathrm{min})$

\section{OXIDE EFFECTIVENESS WITH PROVIDED ENERGY}

The efficiency of oxides is represented by the ratio $\mathrm{R}$. The welding current level represents the energy level supplied to the melt. This energy indirectly represents the temperature reached in the melt. Normally, each oxide has an optimum temperature where it completely fulfills its role. Figure 8 shows that the coefficient $\mathrm{R}$ is more important with current $180 \mathrm{~A}$ in the cases of $\mathrm{TiO}_{2}, \mathrm{SiO}_{2}, \mathrm{Fe}_{2} \mathrm{O}_{3}, \mathrm{MnO}_{2}, \mathrm{CaO}$ but $\mathrm{ZnO}$ and $\mathrm{Cr}_{2} \mathrm{O}_{3}$ oxides are more efficient with a current of $200 \mathrm{~A}$, and finally $\mathrm{ZrO}_{2}$ oxide is efficient with a current of $150 \mathrm{~A}$. Figures 9 and 10 show micrographs of weld beads.

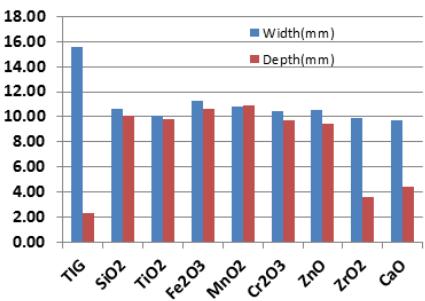

Fig. 7. Morphology of TIG and ATIG welds ( $\mathrm{I}=180 \mathrm{~A}, \mathrm{~V}=15 \mathrm{Cm} / \mathrm{min})$

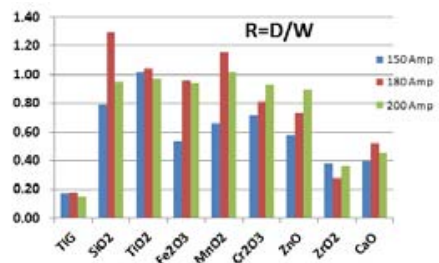

Fig. 8. Width to depth ratio of TIG and ATIG welds ( $\mathrm{I}=150,180,200 \mathrm{~A}$, $\mathrm{V}=15 \mathrm{Cm} / \mathrm{min})$ 


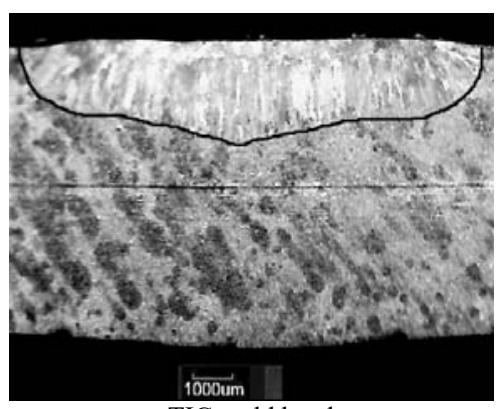

TIG weld bead

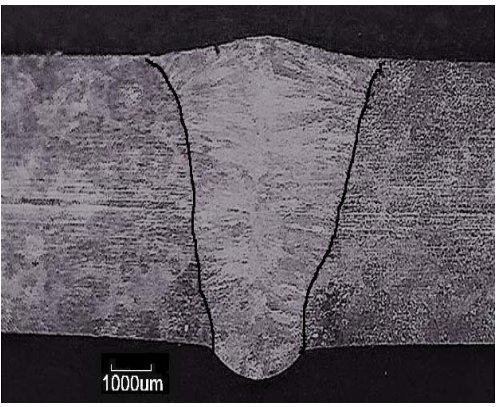

ATIG weld with $\mathrm{Fe}_{2} \mathrm{O}_{3}$ flux

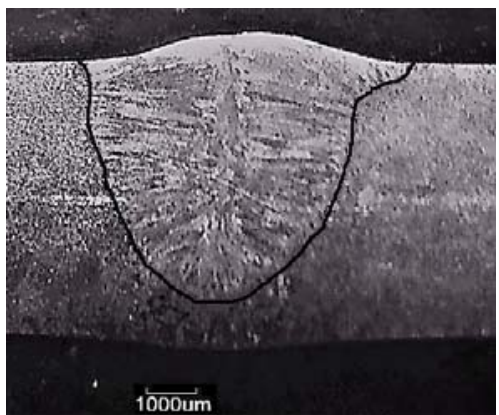

ATIG weld with $\mathrm{ZnO}$ flux

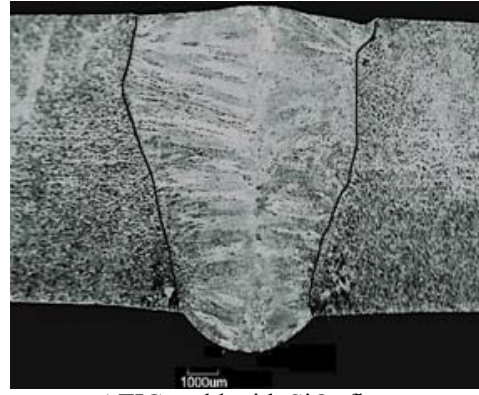

ATIG weld with $\mathrm{SiO}_{2}$ flux

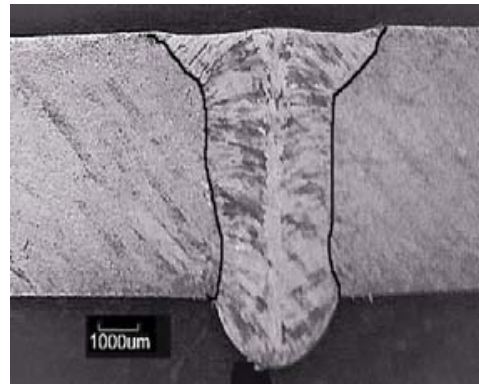

ATIG weld with $\mathrm{MnO}_{2}$ flux

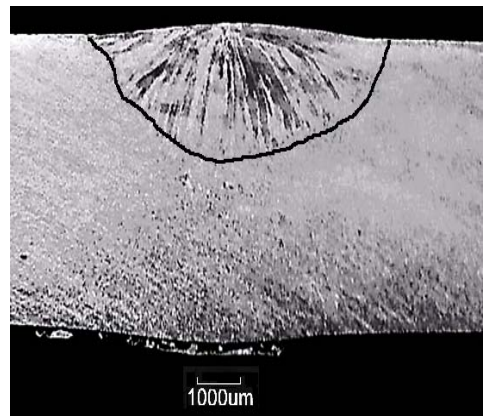

ATIG weld with $\mathrm{ZrO}_{2}$ flux

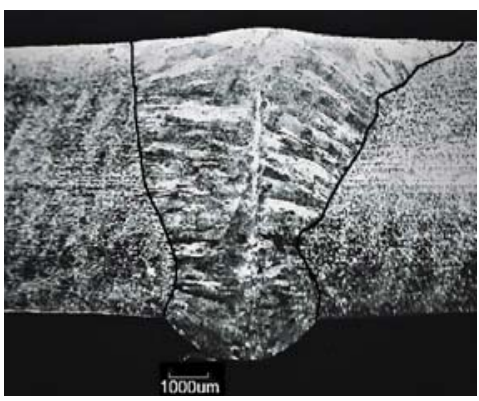

ATIG weld with $\mathrm{TiO}_{2}$ flux

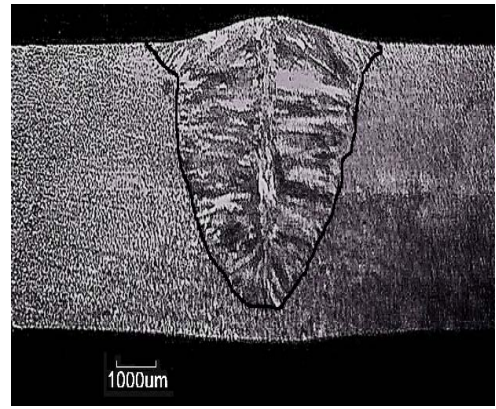

ATIG weld with $\mathrm{Cr}_{2} \mathrm{O}_{3}$ flux

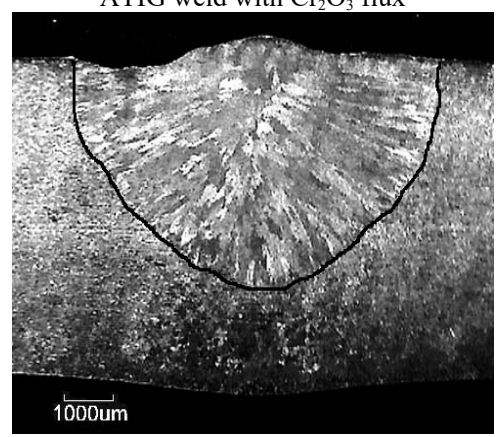

ATIG weld with $\mathrm{CaO}$ flux

Fig. 9. Weld beads using different mono-oxides flux with $180 \mathrm{~A}, 15 \mathrm{Cm} / \mathrm{min}$

\section{EFFECT OF OXIDE FLUXES ON MECHANICAL PROPERTIES}

\section{A. Tensile Test}

The configuration and size of the tensile specimens were prepared according to ASTM E8M-04 for the tensile test as shown in Figure 11. Figure 12 presents the results for the tensile strength of TIG weldment with and without fluxes. It can be clearly seen that the tensile strength obtained by using activating fluxes exhibit are better than those of TIG welding. According to [23, 31, 32], the delta ferrite is formed during ATIG welding. The delta-ferrite has a body-centered cubic (BCC) crystal structure, which has a higher mechanical strength than that of the austenitic FCC structure. It was seen that the content of Ferrite number is greater during the ATIG welding than in TIG welding. It was also observed that during the ATIG the delta-ferrite content in the weld metals was increased, and showing a positive effect in increasing the tensile strength.

\section{B. Hardness Test}

The location of the measurements across the weld cross section is shown in Figure 13. The values used are the average of four measurements.Results showed the same trends as the tensile strength results that the oxide flux did not affect the hardness of welds. The hardness of ATIG welds is equal or above of the TIG welding hardness reading, except ATIG silicon oxide flux weld hardness (165HV) which is less to TIG weld bead hardness $(176 \mathrm{HV})$ as shown in Figure 14. In the other hand $\mathrm{HV}$ hardness of $\mathrm{MnO}_{2}, \mathrm{Cr}_{2} \mathrm{O}_{3}$ and $\mathrm{ZrO}_{2}$ are bigger than the hardness of parent metal (180HV).

\section{Impact Test}

Figure 15 presents the results for the experimental results for the impact test at weld zone of TIG weldment with and without fluxes. The specimens were prepared according to ASTM E23 for the impact test as shown in Figure 16. It can be observed that, except for the titanium dioxide $\mathrm{TiO} 2$, the weldment using the other oxide fluxes exhibits a worse withstand to sudden shock than those of TIG welding. This may be attributed to two reasons: (a) The level of oxygen trapped in the weld pool while welding or due to decomposition of oxides as revealed by XPS analysis and (b) The formation of the ferrite content in ATIG welds decreases to sudden impact loads. Figure 17 presents the results of the experimental results for the impact test at heat affected zone HAZ of TIG weldment with and without fluxes. It can be 
observed that a drastic reduction in the impact toughness, probably due to a formation of sigma phase and coarser ferrite and austenite grains.

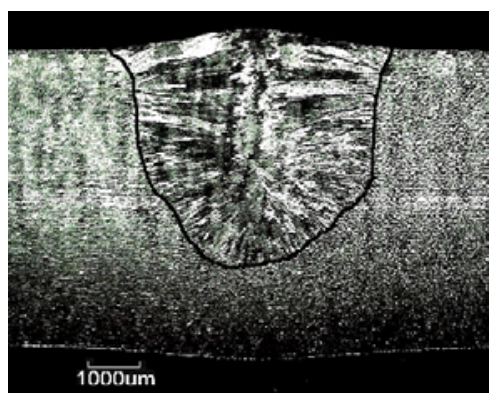

ATIG with $\mathrm{Cr}_{2} \mathrm{O}_{3}$ flux, $\mathrm{I}=150 \mathrm{~A}$

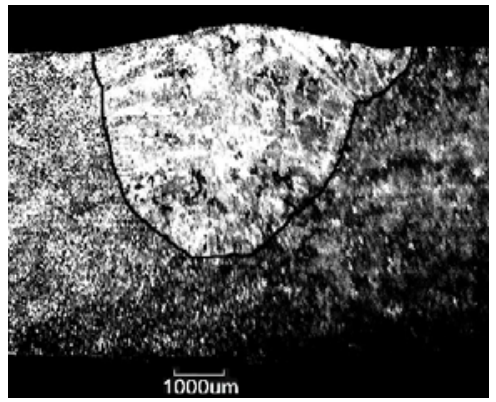

ATIG with $\mathrm{Fe}_{2} \mathrm{O}_{3}$ flux, I=150A

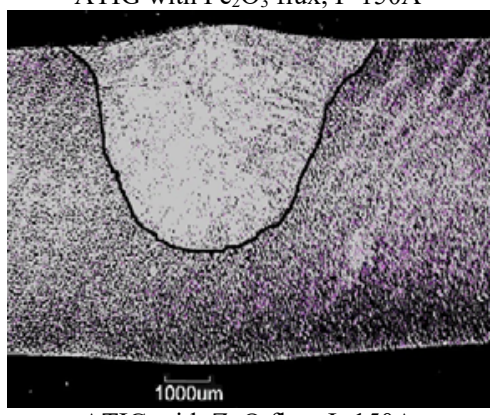

ATIG with $\mathrm{ZnO}$ flux, I=150A

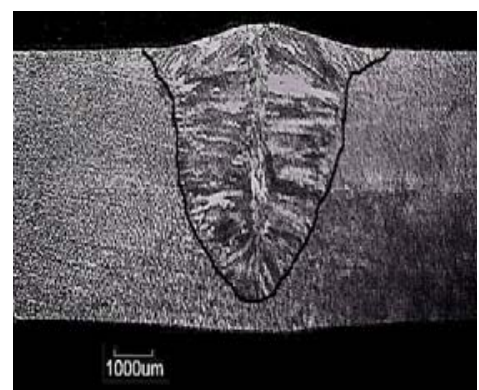

ATIG with $\mathrm{Cr}_{2} \mathrm{O}_{3}$ flux, $\mathrm{I}=180 \mathrm{~A}$

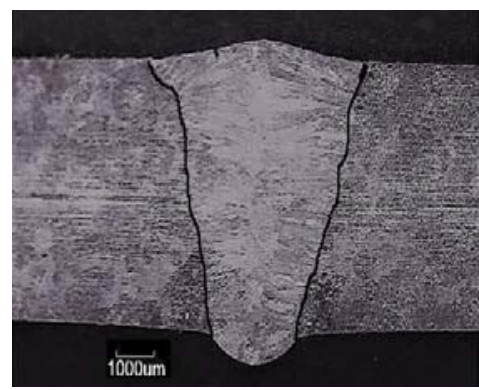

ATIG with $\mathrm{Fe}_{2} \mathrm{O}_{3}$ flux, $\mathrm{I}=180 \mathrm{~A}$

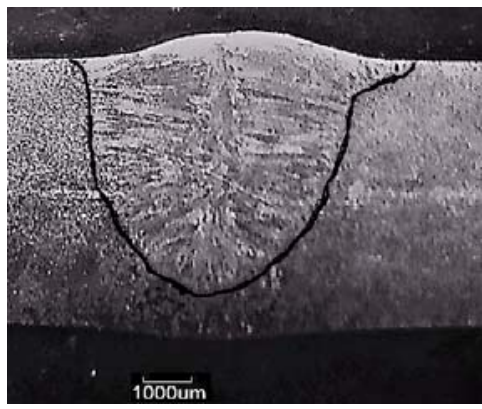

ATIG with ZnO flux, I=180A

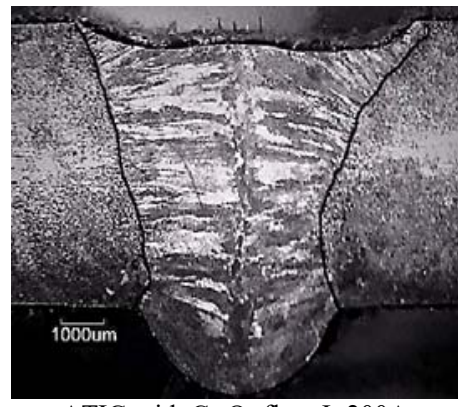

ATIG with $\mathrm{Cr}_{2} \mathrm{O}_{3}$ flux, $\mathrm{I}=200 \mathrm{~A}$

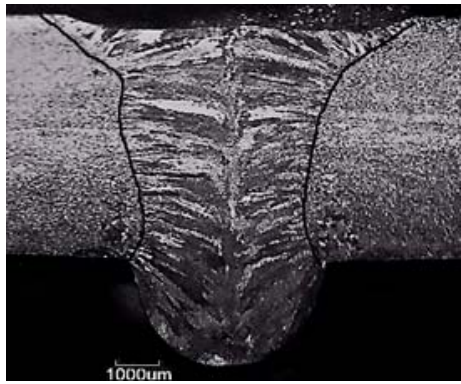

ATIG with $\mathrm{Fe}_{2} \mathrm{O}_{3}$ flux, $\mathrm{I}=200 \mathrm{~A}$

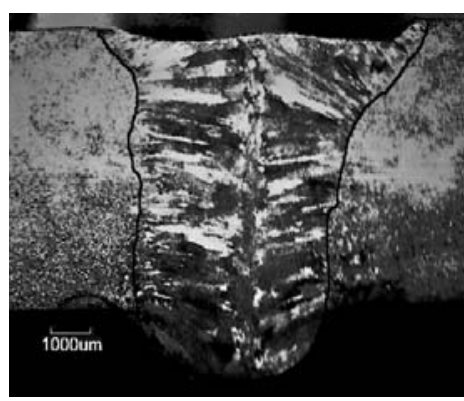

ATIG with ZnO flux,I=200apms

Fig. 10. Weld beads using different levels of current intensity (150- $180-200 \mathrm{~A})$, welding speed $15 \mathrm{Cm} / \mathrm{min}$

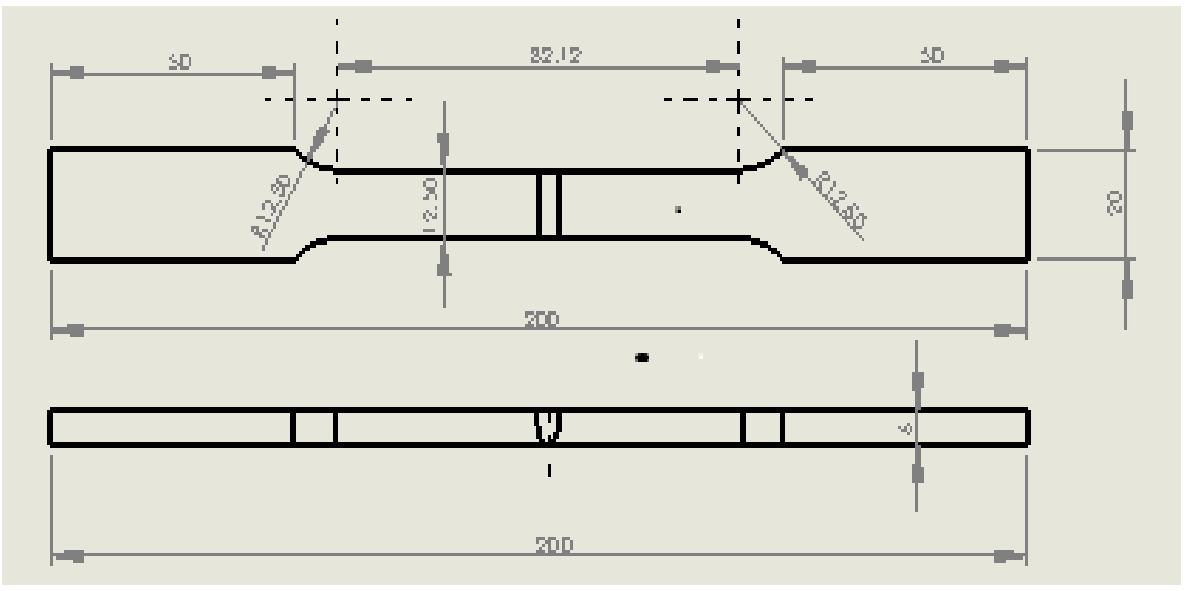

Fig. 11. Test specimen for the tensile test 


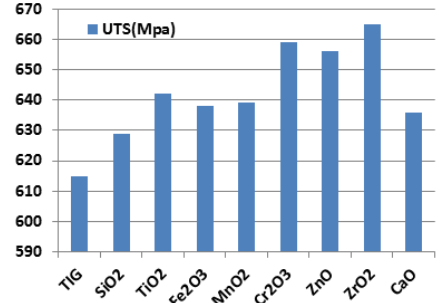

Fig. 12. UTS of TIG and ATIG welds ( $\mathrm{I}=180 \mathrm{~A}, \mathrm{~V}=15 \mathrm{Cm} / \mathrm{min})$

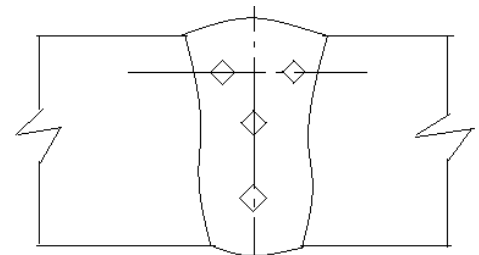

Fig. 13. Hardness test locations on weld bead

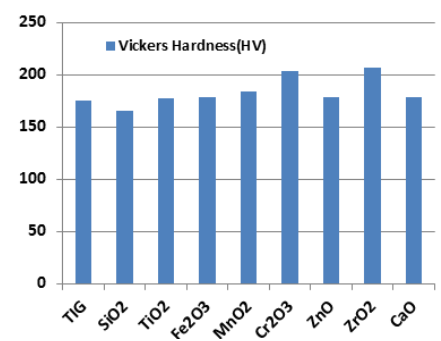

Fig. 14. Vickers hardness for TIG and ATIG welds at weld zone (I=180A, $\mathrm{V}=15 \mathrm{Cm} / \mathrm{min}$ )

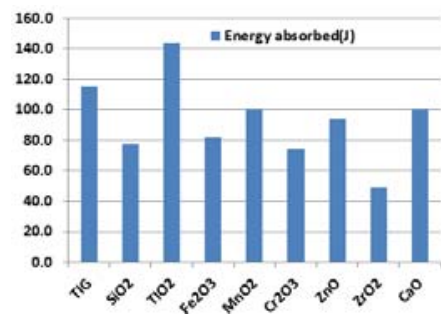

Fig. 15. Energy absorbed for TIG and ATIG welds at weld zone ( $\mathrm{I}=180 \mathrm{~A}$, $\mathrm{V}=15 \mathrm{Cm} / \mathrm{min})$

\section{MicROSTUCTURE}

During welding, weld metal cools so rapidly that the transformation of delta ferrite to austenite is not complete, so, more delta ferrite is retained in the weld metal after solidification. The arc voltage increases when the activated TIG process was used knowing that the heat provided to weld pool is proportional to the voltage. The longer the element in the flux has the ability to influence the voltage, the higher the energy supplied. The measurement of ferrite content in the austenite matrix was performed using Areas image processing software from Microvision as shown in Figure 18 (a)-(d). The study has been conducted on different ATIG welds and TIG conventional weld. Results show a ferrite content equal to 6.8 for TIG. On the other hand there is an increase in ferrite content when using oxide fluxes which vary from 6.9 for $\mathrm{MnO}_{2}$ to 8.4 for $\mathrm{SiO}_{2}$ as shown in Figure 18. The increase of deltaferrite content explains the increase of hardness and strength of the ATIG welds.

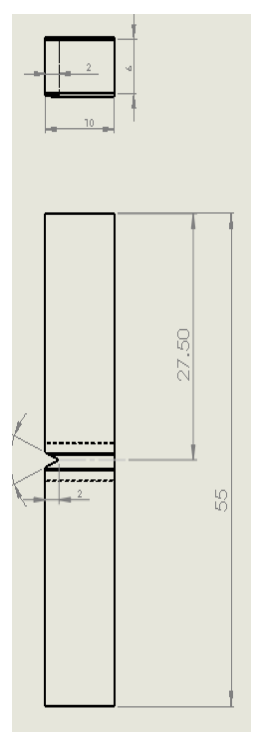

(a)

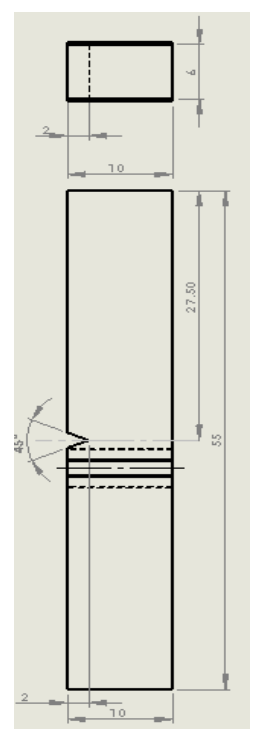

(b)
Fig. 16. Test specimen for the impact test (a) weld zone, (b) HAZ

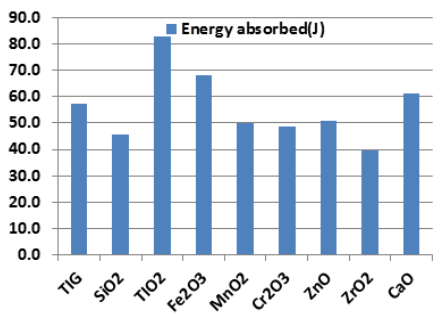

Fig. 17. Energy absorbed for TIG and ATIG welds at HAZ (I=18A, $\mathrm{V}=15 \mathrm{Cm} / \mathrm{min})$

\section{CONCLUSION}

This study was conducted on ATIG welding of austenitic 316L. Eight oxide fluxes were investigated. The results are summarized as follows:

- XPS analysis shows that the percentage of oxygen in the welds decreases with the increase of current welding intensity. This contributes to increase the energy supplied to the melt. This can be explained by the fact that the oxides decompose and the oxygen atoms are transferred to the liquid weld pool allowing to centripetal melt convection.

- The Oxides which are characterized by melting and boiling point close to those of the base metal should be chosen, like $\mathrm{SiO}_{2}, \mathrm{TiO}_{2}, \mathrm{Cr}_{2} \mathrm{O}_{3}$, and $\mathrm{Fe}_{2} \mathrm{O}_{3}$ whose melting and boiling points are close to the ones of austenite stainless steel 316L. It is not a major criterion but it helps to get better welding without loss of energy.

- Oxide fluxes with high thermodynamic stability and high melting points are not advisable to use for austenitic stainless steel $\left(\mathrm{Tm}=1440^{\circ} \mathrm{c}\right)$, like $\mathrm{ZrO}_{2}$ and $\mathrm{CaO}$. 

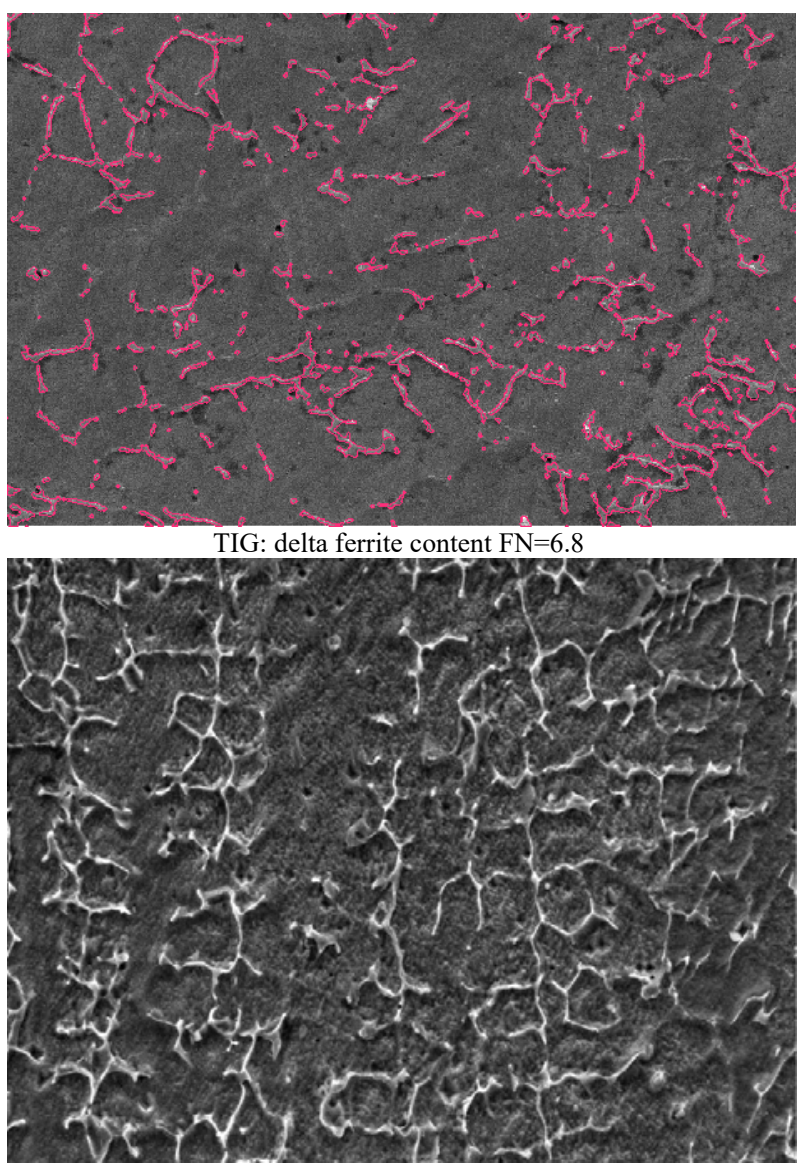

ATIG with flux: $\mathrm{MnO}_{2}$ - delta ferrite content $\mathrm{FN}=6.9$

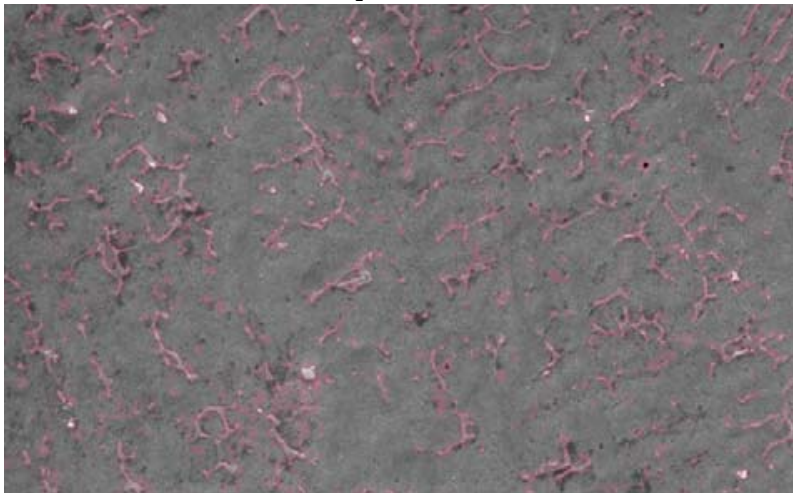

ATIG with flux: $\mathrm{TiO}_{2}$ - delta ferrite content $\mathrm{FN}=7.1$

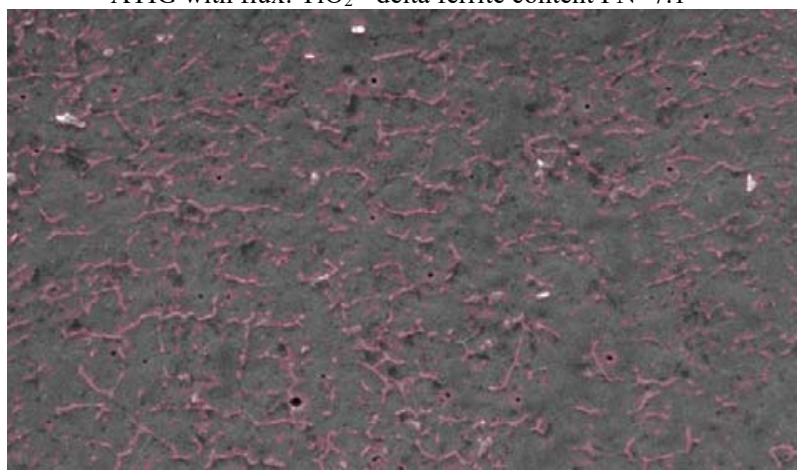

ATIG with flux: $\mathrm{SiO}_{2}$ - delta ferrite content $\mathrm{FN}=8.4$

Fig. 18. Delta-ferrite content for TIG weld (a) and ATIG welds (b,c,d). SEM. Magnification $2500 \mathrm{X}$.
- The optimal geometric ratio of efficiency $\mathrm{R}$ is achieved when $\mathrm{I}=180 \mathrm{~A}, \mathrm{~V}=15 \mathrm{~cm} / \mathrm{min}$ and arc length $=2 \mathrm{~mm}$ for the $316 \mathrm{~L}$ stainless steel using oxide fluxes such as $\mathrm{Si} 2 \mathrm{O}$, $\mathrm{TiO} 2$, $\mathrm{Fe} 2 \mathrm{O} 3$, and $\mathrm{MnO} 2$.

- The tensile strength of ATIG welds are above the TIG or parent metal tensile strength (618MPa). This is due to the formation of delta ferrite which is characterized by its high mechanical strengths.

- The hardness of the welded zone was not affected by the addition of active fluxes.

- Except for the titanium dioxide $\mathrm{TiO} 2$, the weldment using other oxide fluxes exhibits worse withstanding to sudden shock compared to those of TIG welding. This is probably due to oxygen content in welds and the delta ferrite formation.

\section{FUNDING AND ACKNOWLEDGEMENT}

This work is supported by the Deanship of Scientific Research in Prince Sattam Bin Abdulaziz University - KSA under the research project number 2017/01/7373. Authors acknowledge his collaboration and thank Dr. Ibrahim Ali AlSayed for his help in performing XPS analysis.

\section{REFERENCES}

[1] H. Y. Huang, S. W. Shyu, K. H. Tseng, C. P. Chou, "Evaluation of TIG flux welding on the characteristics of stainless steel", Science and Technology of Welding and Joining, Vol. 10, No. 5, pp. 566-573, 2005

[2] S. W. Shyu, H. Y. Huang, K. H. Tseng, C. P. Chou, "Study of the performance of stainless steel A-TIG welds", Journal of Materials Engineering and Performance, Vol. 17, No. 2, pp. 197-201, 2008

[3] S. M. Gurevich, V. N. Zamkov, N. A. Kushnirenk., "Improving the penetration of titanium alloys when they are welded by argon tungsten arc process", Automatic Welding, Vol. 18, No. 9, pp. 1-5, 1965

[4] A. M. Makara, B. N. Kushnirenko, V. N. Zamkov, "High-tensile martensitic steels welded by argon tungsten arc process using flux", Automatic Welding, Vol. 7, pp. 78-79, 1968

[5] A. G. Simonik, "The effect of contraction of the arc discharge upon the introduction of electro-negative elements", Welding Production, Vol. 3, pp. 49-51, 1976

[6] W. Lucas, D. S. Howse, "An investigation into arc constriction by active fluxes for TIG (A-TIG) welding”, Science and Technology of Welding and Joining, Vol. 5, No. 3, pp. 189-193, 2000

[7] W. Lucas, D. S. Howse, "Activating flux - increasing the performance and productivity of the TIG and plasma processes", Welding and Metal Fabrication, Vol. 64, No. 1, pp. 11-17, 1996

[8] C. R. Heiple, J. R. Roper, "Mechanism for minor element effect on GTA fusion zone geometry", Welding Journal, Vol. 61, No. 4, pp. 97s-102s, 1982

[9] C. R. Heiple, J. R. Roper,"Effect of selenium on GTAW fusion zone geometry", Welding Journal, Vol. 60, No.8, pp. 143-145, 1981

[10] C. R. Heiple, J. R. Roper, R. T. Stagner, R. J. Aden, "Surface active element effects on the shape of GTA, Laser, and electron beam welds", Welding Journal, Vol. 62, No. 3, pp. 72-77, 1983

[11] P. S. Korinko, S. H. Malene, "Considerations for the Weldability of Types 304L and 316L Stainless Steels" Journal of Failure Analysis and Prevention, Vol. 1, No. 4, pp. 61-68, 2001

[12] K.-H. Tseng, K.-J. Chuang. "Application of iron-based powders in tungsten inert gas welding for $17 \mathrm{Cr}-10 \mathrm{Ni}-2 \mathrm{Mo}$ alloys", Powder Technology, Vol. 228, pp. 36-46, 2012

[13] C. R. Heiple, J. R. Roper, "Effects of $\mathrm{SO}_{2}$ shielding gas addition on GTA weld shape welding", Welding journal, Vol. 64, No.6, pp. 159s-162s, 1985 
[14] P. Sahoo, T. DebRoy, M. J. McNallan, "Surface tension of binary metal-surface active solute systems under conditions relevant to welding metallurgy", Metallurgical Transactions, Vol. B19, No. 3, pp. 483-491, 1988

[15] J. E. Indacochea, D. L. Olson, "Relationship of weld Metal microstructure and penetration to weld metal oxygen content", Journal of Materials for Energy Systems, Vol. 5, No. 3, pp. 139-148, 1983

[16] H. Tamatsu, K. Nogi, K.Ogino, "Surface tension of liquid iron-oxygen alloy Journal of High Temperature Society, Vol. 18, pp. 14-19, 1992

[17] S. Lu, H. Fujii, H. Sugiyama, M. Tanaka, K. Nogi, "Weld penetration and marangoni convection with oxide fluxes in GTA weldin", Materials Transsactions, Vol. 43, No. 11, pp. 2926-2931, 2009

[18] Q. Li, X. Wang, Z. Zou, J. Wu, "Effect of activating flux on arc shape and arc voltage in tungsten inert gas welding", Transactions of Nonferrous Metals Society of China, Vol. 17, No. 3, pp. 486-490, 2007

[19] R .Duhan, S. Choudhary, "Effect of different fluxes on hardness and microstructure of SS 304 in GTAW welding", International Journal of Mechanical Engineering, Vol. 3, No. 4, pp. 1-8, 2014

[20] T.-S. Chern, K.-H. Tseng, H.-L. Tsai, "Study of the characteristics of duplex stainless steel activated tungsten inert gas welds" Materials and Design, Vol. 32, No. 1, pp. 255-263, 2011

[21] P. J. Modenesi, E. A. R. Apolinario, I. M. Pereira. "TIG welding with single-component fluxes", Journal of Materials Processing Technology, Vol. 99, No. 1-3, pp. 260-265, 2000

[22] P. Vasantharaja, M. Vasudevan, "Studies on A-TIG welding of Low Activation Ferritic/Martensitic (LAFM) steel", Journal of Nuclear Materials, Vol. 421, pp. 117-123, 2012

[23] K.-H. Tseng, C.-Y. Hsu, "Performance of activated TIG process in austenitic stainless steel welds", Journal of Materials Processing Technology, Vol. 211, No. 3, pp. 503-512, 2011

[24] C. Yang, S. Lin, F. Liu, L. Wu, Q. Zhang, "Research on the mechanism of penetration increase by flux in ATIG welding", Journal of Materials Science and Technology -Shenyang, Vol. 19, pp. 225-227, 2003

[25] S. Choudhary, R. Duhan, "Effect of Activated Flux on Properties of SS 304 Using TIG Welding" IJE Transactions B: Applications Vol. 28, No. 2, pp. 290-295, 2015

[26] H.-Y. Huang, "Effects of activating flux on the welded joint characteristics in gas metal arc welding", Materials and Design, Vol. 3, pp. 2488-2495, 2010

[27] B. G. Paul, K. C. Ramesh Kumar, "Effect of single component and binary fluxes on the depth of penetration in a-TIG welding of Inconel alloy $800 \mathrm{H}$ austenitic stainless steel", International Journal of Advanced Engineering and Global Technology, Vol. 5, No. 3, pp. 1791-1795, 2017

[28] K.-H. Tseng, W.-C. Wang, "Study of Silica-Titania Mixed Flux Assisted TIG Welding Process", Advanced Materials Research, Vol. 291-294, 949-953, 2011

[29] A. B. Patel, S. P. Patel, "The effect of activating fluxes in TIG welding by using Anova for SS 321", International Journal of Engineering Research and Applications, Vol. 4, No. 5, pp. 41-48, 2014

[30] G. Venkatesan, J. George, M. Sowmyasri, V. Muthupandi, "Effect of ternary fluxes on depth of penetration in A-TIG welding of AISI 409 ferritic stainless steel", Procedia Materials Science, Vol. 5, pp. 24022410,2014

[31] K.-H. Tseng, K.-L. Chen, "Comparisons Between $\mathrm{TiO}_{2}$ - and $\mathrm{SiO}_{2}-\mathrm{Flux}$ Assisted TIG Welding Processes", Journal of Nanoscience and Nanotechnology, Vol. 12, pp. 6359-6367, 2012

[32] E. Ahmadi, A. R. Ebrahimi, R. Azari Khosroshahi, "Welding of 304 stainless steel with activated tungsten inert gas process", International Journal of ISSI, Vol. 10, No. 1, pp. 27-33, 2013 